Рецензия на: Абусеитова М.X. Казахское ханство. - 2-е издание, переработанное и дополненное. Алматы: Шыгыс пен Батыс, 2020. - 344 с.

\title{
Муканова Г.К
}

Казахский национальный университет имени аль-Фараби,

Алматы, Республика Казахстан.

(iD) https://orcid.org/0000-0002-9222-5893, e-mail: Gulnar_mukanova@mail.ru

Для цитирования: Муканова Г.К. Рецензия на: Абусеитова М.Х. Казахское ханство. - 2-е издание, переработанное и дополненное. - Алматы: Шыгыс пен Батыс, 2020. - 344 с. // Этническая культура. - 2021. - Т. 3, № 3. - С. 51-53. DOI:10.31483/r-99456.

Review: Abuseitova M.Kh. (2020). Kazakh Khanate, 344

\author{
Gulnar K. Mukanova \\ Al-Farabi Kazakh National University, \\ Almaty, Republic of Kazakhstan. \\ https://orcid.org/0000-0002-9222-5893, e-mail: Gulnar_mukanova@mail.ru
}

For citation: Mukanova G.K. (2021). Review: Abuseitova M.Kh. (2020). Kazakh Khanate, 344. Etnicheskaya kultura = Ethnic Culture, 3(3), 51-53. (in Russ.). DOI:10.31483/r-99456.

Монография «Казахское ханство» написана доктором исторических наук, член-корреспондентом Национальной академии наук Республики Казахстан, директором Казахстанского республиканского центра по изучению исторических материалов Института востоковедения имени Р.Б. Сулейменова профессором М.Х. Абусеитовой. Книга опубликована издательством «Шығыс пен Батыс» в городе Алматы в 2020 году, она представляет собой 2-е издание, переработанное и дополненное.

Издание монографии осуществлено при финансовой поддержке Министерства образования и науки Республики Казахстан в рамках научной программы «История и культура Великой степи». С 2018 г. в Казахстане реализуется государственная программа «Архив-2025», ставящая целью сведение фундаментальных исследований отечественных и зарубежных архивов в единый электронно-цифровой фонд.

Рецензируемое издание аккумулирует результаты критического анализа сведений письменных восточных, западноевропейских, русских источников через призму данных археологии, этнографии, а также устной исторической традиции на предмет систематизации этносоциальной и политической истории казахского этноса. Автором монографии уделяется особое внимание исследованию духовного и культурного наследия, взаимодействию и взаимовлиянию восточных и западных культур на просторах Великого шелкового пути. Автор является специалистом в области арабо-персидской письменности, составившей знаковую основу источниковедения по истории и этнологии средневекового Казахстана и Центральной Азии.

М.Х. Абусеитовой предлагаются новые подходы к изучению исторической преемственности и традиций казахской государственности. Исследование аспектов жизнедеятельности этноса, в недавнем прошлом от- носимого к бесписьменным, автором осуществлено на междисциплинарном уровне. Монография содержит такие разделы, как «Устная историческая традиция», «Визуальные источники (артефакты, карты, миниатюры, картины)», «Духовное наследие и взаимовлияние культур на Великом Шелковом пути. Синкретизм верований, религий», «Ренессанс в истории Казахского ханства».

В монографии выделен отдельный раздел «Договор как основной дипломатический акт. Переговоры и посольства. Династический брак» посвящен анализу внешнеполитических и торгово-экономических связей тюрков, а также дипломатического этикета восточных государственных образований [2, с. 184-190]. Целевое погружение в прошлое наряду со знанием восточных языков и переработкой большого массива рукописей и раритетных архивных материалов позволяет отнести рецензируемую монографию к разряду фундаментальных трудов.

Этнологические аспекты казахской государственности выявлены и систематизированы автором издания на базе многолетних археографических исследований в Российской Федерации, Монголии, Китае, Узбекистане, Киргизии, Турции, Франции, Великобритании, Венгрии и Швейцарии. Исследовательская работа в зарубежных архивах и музейных коллекциях позволила выявить уникальные артефакты: восточные миниатюры, каменный саркофаг согдийского предводителя Аньцзя, музыкальные инструменты, через эволюцию которых автором прослеживается миграция этносов и межкультурные заимствования. Кроме того, автором проведен компаративный анализ нумизматических раритетов, например, монет кушанских правителей Канишки и Хувишки [2, с. 97].

Автором осуществлен синтез данных из записок западноевропейских путешественников и послов 
П. Карпини, Гильома де Рубрука, А. Стейна, Э. Шаванна, П. Пелльо, С. Хегина и др., проявлявших интерес к этнокультурным особенностям народов Евразии [2, с. 64-67]. Синкретизм верований, религий на степном пространстве Евразии, считает автор, были той основой, благодаря которой происходил обмен культурными достижениями. «Христианство (несторианство), буддизм, манихейство, тенгрианство, шаманизм, ислам адаптировались в традиционной культуре Центрально-Азиатского региона и интегрировались в нее» [2, с. 98].

Среди вводимых автором монографии в научный оборот материальных источников по этнической истории казахов особое место занимают наскальные изображения. По убеждению М. Абусеитовой, «атрибуты в каменных изваяниях дают представление о военной иерархии, военном деле, расселении этносов (этногеографии), мировоззрении тюрков и др.» [2, с. 99]. Логичным представляется обращение автора на символы власти правителей, сфрагистику, солярные и иные изображения, дающие представление о сакральных предпочтениях насельников территории Казахстана и смежных областей.

Данное издание является ключом к пониманию закономерно обусловленной преемственности в изучении истории и этнологии Казахстана. Казахстанское обществоведение прошло тернистый путь. Пионером изучения прошлого казахского народа по праву считается ученый-этнограф, географ Ч. Валиханов (1835$1865)$, чья короткая жизнь была посвящена как науке, так и опасным путешествиям [5]. Одним из первых приступил к написанию учебника по истории Казахстана С.Д. Асфендияров [3]. Нарком просвещения Казахской республики С. Садвокасов (1900-1933) в своих выступлениях в середине 1920 гг., когда большевики отрицали научные открытия Ч. Валиханова, поэзию А. Кунанбаева, роль исторической личности хана Абылая, этнопедагогику И. Алтынсарина и др., отстаивал их заслуги [см.: 7].

В послевоенном Казахстане репрессии подвергся коллектив авторов издания «История Казахстана», в их числе и Е.Б. Бекмаханов [4]. В те годы этнологические и антропологические исследования вовсе были отнесены к буржуазным, в частности, был уничтожен набранный тираж монографии антрополога О.И. Исмагулова [6]. Для суверенного Казахстана ныне изучение культурного наследия является основой понимания казахской самоидентичности, ментальности, государственности и национальной идеи в условиях глобализации.

Рецензируемый труд М.X. Абусеитовой является богато дополненным и переработанным изданием ранней монографии [1]. В издании 1985 г. анализу были подвергнуты проблемы развития казахской государственности и народности во второй половине XVI в., на основе преимущественно персоязычных исторических источников XVI-XVII вв. Новое издание, которое по феноменологической компоненте следует классифицировать как интереснейший коммуникативный инструмент для специалистов и всех интересующихся восточными социумами, насыщено разножанровой информацией и опирается на более широкую базу источников.

В приложении читатель прикоснется к богатой кладези уникальных источников: книгу дополнили извлечения из «Тарих-и джахангушай» Джувайни, «Чингиз-наме» Утемиша-хаджи, «Бахр ал-асрар фи манакиб ал-ахйар» Махмуда ибн Вали, равно как переписка правителей с соседними государствами, иллюстративные материалы из коллекций по нумизматике и сфрагистике, уникальных географических и геополитических карт [2, с. 282-140]. Издание прекрасно иллюстрировано копиями миниатюр и рукописей из Британской библиотеки (Лондон), Рампур (Индия), Научной библиотеки Казанского университета, из Фонда Анри Мозера Бернского исторического музея (Берн, Швейцария), Национальной библиотеки (Алматы, Казахстан), Лувра и Национальной библиотеки Франции (Париж), музеев под открытым небом Монголии, КНР [2, с. 73, 169, 241]. Все эти материалы были выявлены во время археографических экспедиций в ходе выполнения грантовых проектов под руководством профессора М.X. Абусеитовой.

В ходе многолетнего исследования М.X. Абусеитовой получены интереснейшие результаты, которые могут быть рекомендованы к применению в практике вузовской и академической подготовки профессиональных кадров этнологов, при создании музейных коллекций и модернизации дизайнерской линейки национального стиля одежды, архитектуры и зодчества.

Монография М.X. Абусеитовой является значительной историко-этнологической работой в области изучения кочевых цивилизаций и казаховедения в частности.

\section{Список литературы}

1. Абусеитова М.X. Казахское ханство во второй половине XVI века. - Алма-Ата: Наука, 1985. - 104 с.

2. Абусеитова М.X. Казахское ханство. - 2-е издание, перераб. и доп. - Алматы: Шыгыс пен Батыс, 2020. -344 c.

3. Асфендиаров С.Д. История Казахстана (с древнейших времен). Том 1. - Алма-Ата. - М.: Казахское краевое издательство, 1935. - 260 с.

4. Бекмаханов Е.Б. Казахстан в 20-40-е годы ХІХ в. - М., 1948. - 400 с.

5. Валиханов Ч.Ч. Сочинения Чокан Чингисовича Валиханова. - СПб.: Типография главного управления уделов, 1904. - $624 \mathrm{c.}$

6. Исмагулов О.И. Этническая антропология Казахстана. - Алма-Ата: Наука, 1982. - 93 с.

7. Муканова Г.К. Центральная Азия и проблемы деколонизации. Антология интеллектуальной истории. Саарбрюккен: LAP, 2013. - 256 с. 


\section{References}

1. Abuseitova, M. Kh. (1985). Kazakhskoe khanstvo vo vtoroi polovine KhVI veka., 104. Alma-Ata: Nauka.

2. Abuseitova, M. Kh. (2020). Kazakhskoe khanstvo., 344. Almaty: Shygys pen Batys.

3. Asfendiarov, S. D. (1935). Istoriia Kazakhstana (s drevneishikh vremen). Tom 1., 260. M.: Kazakhskoe kraevoe izdatel'stvo.

4. Bekmakhanov, E. B. (1948). Kazakhstan v 20-40-e gody XIX v., 400. M.

5. Valikhanov, Ch. Ch. (1904). Sochineniia Chokan Chingisovicha Valikhanova., 624. SPb.: Tipografiia glavnogo upravleniia udelov.

6. Ismagulov, O. I. (1982). Etnicheskaia antropologiia Kazakhstana., 93. Alma-Ata: Nauka.

7. Mukanova, G. K. (2013). Tsentral'naia Aziia i problemy dekolonizatsii. Antologiia intellektual'noi istorii., 256. Saarbriukken: LAP.

\section{Информация об авторе}

Муканова Гюльнар Кайроллиновна - канд. ист. наук, профессор, профессор кафедры

Казахского национального университета

имени аль-Фараби», Алматы, Республика Казахстан.

\section{Information about the author}

Gulnar K. Mukanova - candidate of historical sciences, professor, professor of the department of Al-Farabi Kazakh National University, Almaty, Republic of Kazakhstan.

Поступила в редакцию / Received 24.08.2021

Принята к публикации / Accepted 29.09.2021

Опубликована / Published 29.09.2021 